\title{
APPLICATION OF SPATIAL STATISTICS IN THE ANALYSIS OF EUROPEAN FUNDS USAGE IN PROVINCES IN POLAND
}

\author{
Katarzyna Warzecha, Andrzej Wójcik
}

\begin{abstract}
This paper carried out a statistical analysis of projects co-financed by the Structural Funds in the years 2004-2013. The analysis was conducted in terms of regions. In particular, provinces had different priorities in terms of content projects co-financed by the European Funds. This is due to the different geographical location, degree of urbanization and population density of each subregion. This paper verifies the hypothesis of the existence of neighboring provinces, which obtain subsidies at the approximate level from European funds for the projects executing specific aims. The use of spatial statistics allows to investigate the existence of spatial dependence for the studied regions thanks to the use of European funds.
\end{abstract}

Keywords: European funds, global and local Moran's I statistics, spatial analysis.

JEL Classification: C38, C23.

DOI: $10.15611 / \mathrm{me} .2016 .12 .06$.

\section{Introduction}

In implementing the cohesion policy, the European Union aims to reduce disparities in the development of particular countries and regions through $\mathrm{Eu}-$ ropean funds. The overriding aim of this policy is the increase of the competitiveness of the European Union's economy on the world markets. Between 2004 and 2013 Poland received over PLN 365 billion from European funds. Funds allocated to Poland for the period of 2014-2020 amount to $€ 82.5$ billion. The disbursement of such financial resources requires coordination at central level, therefore the documents determining the strategy of European Union development are being created and, consequently, the domestic documents regulating the strategy of development for individual countries are being developed as well. The National Strategic Plan which was applied in Poland between 2004 and 2006, and the National Cohesion Strategy for 20072013 were the basis for many implemented programmes. The aim of those 
programmes was the reduction of disparities between particular provinces and the growth of competitiveness of the economy in particular provinces, as well as in the whole country.

This paper verifies the hypothesis of the existence of neighboring provinces which obtain the subsidies at the approximate level from European funds for the projects achieving specific aims. This hypothesis results from the assumption that if European Union policy should lead to the balance in levels of development of particular regions, the most impoverished provinces should receive the most substantial financial support for the implemented projects, and at the same time their aims should be convergent.

The data used for the calculations comes from the website - the European Union Grants Map [www1]. The spatial statistics (global and local measures of spatial autocorrelation) in the analysis of European funds usage in provinces in Poland in 2004-2013 with the use of the R Cran and Microsoft Office Excel.

\section{European funds usage in provinces}

87,635 projects co-financed by the European Union have been realized between 2004 and 2006. The global value of all the projects amounts to approximately PLN 98,5 billion, and on the part of the European Union co-financing PLN 52260 million. In the case of the 2007-2013 period, the number of co-financed programmes increased to 100190. While the increase of the number of projects was insignificant, the increase of the value of projects realized and the amount of funding were substantial, PLN 566,8 billion and PLN 311,9 billion respectively. The amounts were spent for particular purposes. There are 15 objectives, which are grouped in 5 categories, see Table 1 . 1 and 2 .

The amount of project subsidy in particular counties is shown in Figures

Both in 2004-2006 and in 2007-2013 the most substantial project subsidy was granted to companies and institutions from provinces such as mazowieckie and śląskie. The smallest amounts were granted in opolskie province. Because the quantity and the value of projects co-financed by the European Union depend on the number of residents in particular provinces, the amount of subsidy is calculated per resident - Figure 2 .

The amount of subsidy was divided by the number of residents of provinces in 2006 and in 2013 respectively. 
As presented in Figure 2, the amounts of subsidies for realized projects were divided by the number of residents from 2006 and 2013 respectively. In 2004-2006 the most substantial subsidy per 1 resident was granted in these provinces: zachodniopomorskie, mazowieckie, dolnośląskie and ślaskie, the least substantial subsidy was allocated in the małopolskie, podkarpackie and świętokrzyskie provinces. In the period 2007-2013 the order was opposite the most substantial subsidy per 1 resident was granted in the warmińsko-mazurskie, podkarpackie, łódzkie and mazowieckie provinces, while the least substantial subsidy appeared in the śląskie, wielkopolskie and opolskie provinces.

Table 1. Objectives connected with the EU co-financed projects

\begin{tabular}{|c|c|}
\hline Category & Objective \\
\hline \multirow{3}{*}{ Education } & Science and education \\
\hline & Research, development, innovations \\
\hline & Culture and the arts \\
\hline \multirow{3}{*}{ Administration } & Administration \\
\hline & International cooperation \\
\hline & Security \\
\hline \multirow{2}{*}{ Environment } & Environmental protection \\
\hline & Revitalization \\
\hline \multirow{2}{*}{ Employment and development } & Employment and social integration \\
\hline & Development of companies \\
\hline \multirow{5}{*}{ Other objectives } & Energy \\
\hline & Transport \\
\hline & Tourism \\
\hline & Telecommunications and e-services \\
\hline & Healthcare \\
\hline
\end{tabular}

Source: own elaboration. 


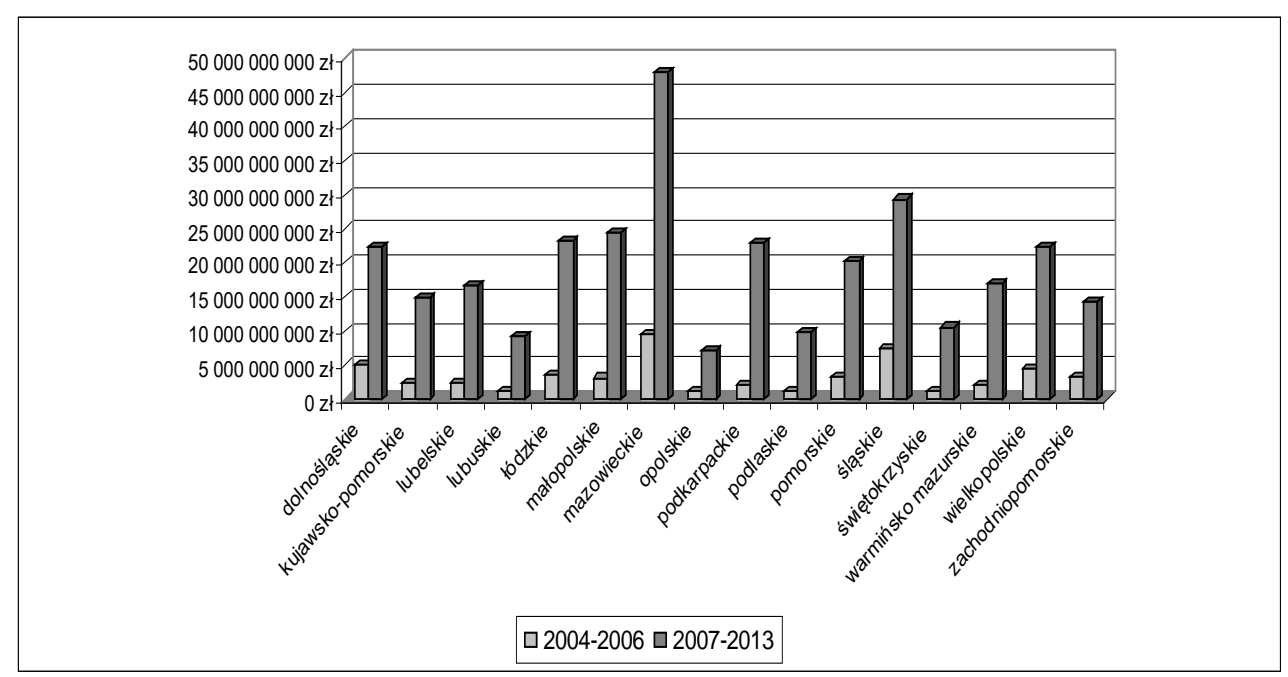

Fig. 1. Amount of subsidy for projects co-financed from European funds in particular provinces, in PLN

Source: own elaboration.

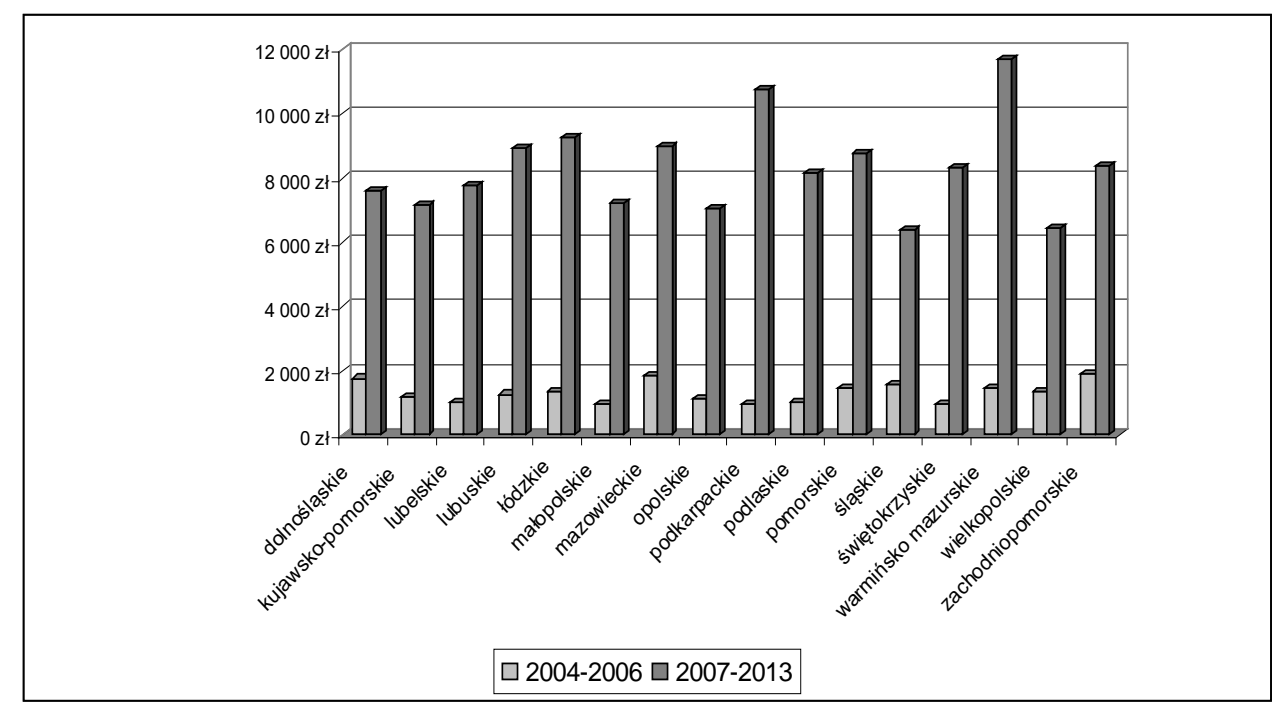

Fig. 2. Amount of subsidy for projects co-financed from European funds per 1 province resident, in PLN

Source: own elaboration.

Any further analyses were conducted for the amount of subsidy per 1 resident (or 1000 residents). 
Table 2. Provinces with the most substantial subsidy per 1 resident classified according to projects' objectives

\begin{tabular}{|c|c|c|}
\hline Project objectives & 2004-2006 period & 2007-2013 period \\
\hline Science and education & $\begin{array}{l}\text { świętokrzyskie, lubuskie, } \\
\text { podkarpackie }\end{array}$ & $\begin{array}{l}\text { podlaskie, świętokrzyskie, } \\
\text { lubelskie }\end{array}$ \\
\hline Energy & $\begin{array}{l}\text { lubelskie, podlaskie, } \\
\text { kujawsko-pomorskie }\end{array}$ & $\begin{array}{l}\text { zachodniopomorskie, } \\
\text { podlaskie, lubuskie }\end{array}$ \\
\hline Transport & $\begin{array}{l}\text { dolnośląskie, mazowieckie, } \\
\text { śląskie }\end{array}$ & $\begin{array}{l}\text { warmińsko-mazurskie, } \\
\text { podkarpackie, łódzkie }\end{array}$ \\
\hline Tourism & $\begin{array}{l}\text { warmińsko-mazurskie, } \\
\text { świętokrzyskie, pomorskie }\end{array}$ & $\begin{array}{l}\text { warmińsko-mazurskie, } \\
\text { podlaskie, świętokrzyskie }\end{array}$ \\
\hline Security & $\begin{array}{l}\text { lubuskie, podlaskie, } \\
\text { warmińsko-mazurskie }\end{array}$ & $\begin{array}{l}\text { opolskie, dolnośląskie, } \\
\text { pomorskie }\end{array}$ \\
\hline $\begin{array}{l}\text { Research, development, } \\
\text { innovations }\end{array}$ & $\begin{array}{l}\text { mazowieckie, zachodnio- } \\
\text { pomorskie, małopolskie }\end{array}$ & $\begin{array}{l}\text { podkarpackie, mazowieckie, } \\
\text { małopolskie }\end{array}$ \\
\hline Culture and the arts & wielkopolskie & $\begin{array}{l}\text { dolnośląskie, mazowieckie, } \\
\text { zachodniopomorskie }\end{array}$ \\
\hline Healthcare & $\begin{array}{l}\text { kujawsko-pomorskie, } \\
\text { podlaskie, mazowieckie }\end{array}$ & $\begin{array}{l}\text { świętokrzyskie, zachodnio- } \\
\text { pomorskie, lubelskie }\end{array}$ \\
\hline $\begin{array}{l}\text { The development } \\
\text { of companies }\end{array}$ & $\begin{array}{l}\text { podlaskie, zachodniopomor- } \\
\text { skie, kujawsko-pomorskie }\end{array}$ & $\begin{array}{l}\text { warmińsko-mazurskie, } \\
\text { zachodniopomorskie, } \\
\text { lubelskie }\end{array}$ \\
\hline $\begin{array}{l}\text { Telecommunications } \\
\text { and e-services }\end{array}$ & $\begin{array}{l}\text { kujawsko-pomorskie, } \\
\text { podlaskie, łódzkie }\end{array}$ & $\begin{array}{l}\text { podlaskie, podkarpackie, } \\
\text { warmińsko-mazurskie }\end{array}$ \\
\hline $\begin{array}{l}\text { Employment and social } \\
\text { integration }\end{array}$ & $\begin{array}{l}\text { warmińsko-mazurskie, } \\
\text { zachodniopomorskie, } \\
\text { podlaskie }\end{array}$ & $\begin{array}{l}\text { świętokrzyskie, warmińsko- } \\
\text { mazurskie, lubelskie }\end{array}$ \\
\hline $\begin{array}{l}\text { International } \\
\text { cooperation }\end{array}$ & $\begin{array}{l}\text { zachodniopomorskie, } \\
\text { dolnośląskie, podlaskie }\end{array}$ & $\begin{array}{l}\text { podlaskie, podkarpackie, } \\
\text { małopolskie }\end{array}$ \\
\hline Administration & $\begin{array}{l}\text { mazowieckie, zachodnio- } \\
\text { pomorskie, lubuskie }\end{array}$ & $\begin{array}{l}\text { mazowieckie, warmińsko- } \\
\text { mazurskie, opolskie }\end{array}$ \\
\hline Revitalization & $\begin{array}{l}\text { podlaskie, świętokrzyskie, } \\
\text { lubelskie }\end{array}$ & $\begin{array}{l}\text { śląskie, świętokrzyskie, } \\
\text { warmińsko-mazurskie }\end{array}$ \\
\hline $\begin{array}{l}\text { Environmental } \\
\text { protection }\end{array}$ & $\begin{array}{l}\text { zachodniopomorskie, } \\
\text { śląskie, opolskie }\end{array}$ & $\begin{array}{l}\text { lubuskie, małopolskie, } \\
\text { zachodniopomorskie }\end{array}$ \\
\hline
\end{tabular}

Source: own elaboration. 
The provinces with the most substantial subsidy per 1 resident were classified according to project objectives and the results are presented in Table 2.

It is worth noting that in 2004-2006 and in 2007-2013 there is a considerable discrepancy between provinces with the most substantial subsidy for the projects connected with particular objectives. The provinces which in 20042006 could be qualified as those with the most substantial subsidy granted, on rare occasions they could be found among the same group in 2007-2013.

\section{Spatial statistics - global and local measures}

Spatial statistics are a convenient and effective way of testing the existence of spatial autocorrelation processes, and the spatial autocorrelation indicates that nearby geographical observations are more similar to each other than distant observations [Kopczewska 2011, p. 69]. If positive autocorrelation occurs in a certain observed area, this means that there is a spatial accumulation, in terms of the location, of high or low values of the observed variables. This indicates that areas with high values of a particular variable are clustered only with other high value areas, and the areas with low values of a particular variable are clustered only with other low value areas. In the case of negative autocorrelation, the high values are neighboring to low ones, and the low values are neighboring to high ones creating the alternating areas with dissimilar values of particular variables (so called checkerboard). The nonspatial autocorrelation indicates spatial randomness, which means that the high and low values of the observed variables are distributed independently [cf. Suchecki 2010, p.103].

The measures of global autocorrelation: Moran's $I$ statistics and local autocorrelation (local Moran's $I_{\mathrm{i}}$ statistics) were taken into consideration in this research.

The global autocorrelation results from the existence of correlations within the whole tested spatial unit (global measure is the single-digit indicator of autocorrelation or the general similarity of regions). In contrast, the local statistics designated for every area answer the question whether the given area is similar/dissimilar to the neighboring areas [cf. Kopczewska 2011, p. 69]. 


\section{The Global Moran's spatial autocorrelation statistics}

The Global Moran's I statistics is used to test the existence of global spatial autocorrelation and it is defined as follows (Formula 1):

$$
I=\frac{n \cdot \sum_{i} \sum_{j} w_{i j}\left(x_{i}-\bar{x}\right)\left(x_{j}-\bar{x}\right)}{\sum_{i} \sum_{j} w_{i j} \cdot \sum_{i}\left(x_{i}-\bar{x}\right)^{2}},
$$

where: $x_{i}, x_{j}$ are the values of variables in spatial unit $i, j ; \bar{x}$ is the average value of variable for all of the spatial units; $n$ is the total number of spatial units that are included in the study; $w_{i j}$ is an element of spatial weights matrix.

The basic element of spatial analysis is determining the structure of neighborhood with the use of so called spatial weights. The spatial weights matrix can be defined by two categories of neighbors: contiguity based neighbors and distance based neighbors. In the research, it is assumed that mutual interactions between provinces, which share boundaries, occur. Therefore the binary matrix is created (taking the value of 1 when the provinces are adjacent, i.e. when they share boundaries, or taking the value of 0 when the provinces are not neighboring). The matrix created in such a manner is row-standardized, allowing the comparison of results of various areas that have been tested.

The positive and significant values of Moran's $I$ statistics indicate the existence of spatial autocorrelation, i.e. the similarity between the tested objects in specific distance $d$. The negative values of Moran's I statistics indicate the negative autocorrelation, i.e. the dissimilarity of the tested objects. The values of the statistic which equal 0 indicate the lack of spatial autocorrelation.

The graphic presentation of the Global Moran's I statistics is the scatter plot (Moran scatter plot), which shows local spatial associations (clusters), non-standardized observations - outliers and spatial instabilities [Anselin 1995, pp. 93-115]. The standardized value of the tested variable (here it is Hellwig's measure of development) is present on the OX axis, and the tested standardized variable with the spatial lag can be found on the OY axis.

The graph divides into quarters in relation to point $(0,0)$. The points situated in the bottom left quarter (LL) indicate the positive spatial autocorrelation and the low values of the variable. The points situated in the top right quarter $(\mathrm{HH})$ indicate the positive spatial autocorrelation and the high values of the variable. The points situated in the top left quarter (HL) indicate the 
negative spatial autocorrelation and the high values of the variable whereas the points situated in the bottom right quarter ( $\mathrm{LH})$ indicate the negative spatial autocorrelation and the low values of the variable. In the described Moran scatter plot the direction coefficient of linear regression is the Global Moran's $I$ statistics (and it is interpreted as the intensity of the association between the level of financial support from European funds and geographical location of provinces, therefore it informs what percentage of the tested phenomenon occurs in the particular area-province and results from the values of this phenomenon in neighboring regions-provinces) [cf. Kopczewska 2011, pp. 72-75].

\section{The Local Moran statistics of spatial autocorrelation}

The local Moran $I_{i}$ statistics allows for the identification of spatial accumulation and measures whether the given spatial unit - province is surrounded by neighboring units with similar or dissimilar values of the tested variable in relation to the random distribution of these values in space and it is determined by Formula 2 [Kopczewska 2011, p. 90]:

$$
I_{i}=\frac{\left(x_{i}-\bar{x}\right) \sum_{i=1}^{n} w_{i j}\left(x_{j}-\bar{x}\right)}{\sum_{i=1}^{n} \frac{\left(x_{i}-\bar{x}\right)^{2}}{n}}
$$

where: $w_{i j}$ are the elements of the first order row-standardized spatial weights matrix W, the other elements of the formula are defined as in the Global Moran's I statistics.

If the standardized Local Moran $I_{i}$ statistics takes significantly negative values it indicates that the object $i$ is surrounded by the spatial units-provinces with significantly dissimilar values of the tested variable, which should be interpreted as the negative autocorrelation. When the $I_{i}$ statistics takes the values significantly positive it indicates that the object $i$ is surrounded by the similar neighboring spatial units-provinces and we deal with the positive autocorrelation and clustering of the spatial units. 


\section{Spatial analysis of the level of subsidy for the projects co-funded from European funds}

The aim of the conducted research is the analysis of the level of subsidy for the projects, co-funded from European funds, which realize certain objectives in particular provinces in Poland with the use of spatial statistics.

The level of European funds subsidy for the projects which were obtained to fulfill certain objectives in provinces has been characterized with the use of a synthetic taxonomic measure of development of Z. Hellwig (the description of the measure: [Zeliaś 2000; Zeliaś 1989; Warzecha 2009], which allows us to arrange the tested objects (Polish provinces) as regards the tested phenomenon). Synthetic measures replace the description of the objects with the use of the set of diagnostic features described by means of the one aggregated quantity. They enable the numeral description of composite phenomena which could not be measured directly [Berbeka 2006, p. 45].

The phases of construction of the synthetic measure of development:

1. In the analysis of the conducted research the significant influence on the research results is exerted by the selection of diagnostic features characterizing described phenomenon ${ }^{2}$. The level of the obtained European funds subsidy has been characterized with the means of the variables determining various aspects of this level (the amount of projects subsidy for the particular purposes per 1000 residents) - Table 1 .

2. The normalization of the values of diagnostic variables ${ }^{3}\left(x_{i j}\right)$ is necessary because the diagnostic variables existing in the research are featured in various units of measure, therefore they cannot be the direct subject to aggregation.

3. The creation of the formula, i.e. the object, which possesses the most favorable values of diagnostic variables $\left(z_{0 j}=\max _{i}\left\{z_{i j}\right\}\right)$, where: $z_{i j}$ is the normalized value.

\footnotetext{
2 The well-chosen diagnostic variables should [Heffner, Gibas 2007, p. 14]: fulfill a significant role in the description of the analyzed phenomenon; be included in interval or ratio scale; be barely correlated to avoid the duplication of data and should be characterized by the high level of variability.

3 All of the variables have been normalized with the use of zero unitarization method according to the formula: $z_{i j}=\frac{x_{i j}-\min x_{i j}}{\max x_{i j}-\min x_{i j}}$ where: $\min x_{i j}-\min$ of a variable $x_{i}$; $\max x_{i j}$ max of variable $x_{i}$.
} 
4. To determine Euclidean distance of every object from the formula $\left(d_{i}\right)$.

5. The calculation of taxonomic measure of development of Z. Hellwig $\left(z_{i}\right)$. The synthetic measure of development takes the values ranging from $[0,1]$. The higher the value of this indicator indicates the more favorable position of the object.

Table 3. Values of synthetic measure for Polish regions in 2004-2006 defined according to Hellwig's method

\begin{tabular}{|c|c|c|c|c|c|c|c|c|c|c|}
\hline \multirow{3}{*}{ Province } & \multicolumn{10}{|c|}{ Synthetic measure according to Hellwig's method } \\
\hline & \multicolumn{2}{|c|}{ Education } & \multicolumn{2}{|c|}{ Administration } & \multicolumn{2}{|c|}{ Environment } & \multicolumn{2}{|c|}{$\begin{array}{c}\text { Employment and } \\
\text { development }\end{array}$} & \multicolumn{2}{|c|}{ Other } \\
\hline & $Z_{i}$ & Rank & $z_{i}$ & Rank & $Z_{i}$ & Rank & $z_{i}$ & Rank & $z_{i}$ & Rank \\
\hline Dolnośląskie & 0.146 & 12 & 0.301 & 4 & 0.144 & 13 & 0.260 & 12 & 0.091 & 14 \\
\hline $\begin{array}{l}\text { Kujawsko- } \\
\text { pomorskie }\end{array}$ & 0.048 & 15 & 0.153 & 10 & 0.393 & 3 & 0.514 & 6 & 0.329 & 4 \\
\hline Lubelskie & 0.116 & 13 & 0.202 & 7 & 0.126 & 15 & 0.578 & 4 & 0.367 & 1 \\
\hline Lubuskie & 0.203 & 7 & 0.227 & 5 & 0.200 & 11 & 0.246 & 14 & 0.158 & 10 \\
\hline Łódzkie & 0.186 & 8 & 0.030 & 16 & 0.241 & 10 & 0.262 & 11 & 0.243 & 5 \\
\hline Małopolskie & 0.287 & 3 & 0.132 & 11 & 0.284 & 7 & 0.160 & 15 & 0.025 & 16 \\
\hline Mazowieckie & 0.259 & 5 & 0.305 & 3 & 0.368 & 4 & 0.482 & 7 & 0.165 & 9 \\
\hline Opolskie & 0.169 & 11 & 0.197 & 8 & 0.469 & 2 & 0.258 & 13 & 0.141 & 12 \\
\hline Podkarpackie & 0.249 & 6 & 0.211 & 6 & 0.303 & 5 & 0.333 & 10 & 0.141 & 13 \\
\hline Podlaskie & 0.080 & 14 & 0.366 & 1 & 0.161 & 12 & 0.903 & 1 & 0.339 & 2 \\
\hline Pomorskie & 0.015 & 16 & 0.115 & 13 & 0.253 & 9 & 0.457 & 8 & 0.167 & 8 \\
\hline Śląskie & 0.178 & 9 & 0.086 & 14 & 0.046 & 16 & 0.116 & 16 & 0.189 & 6 \\
\hline Świętokrzyskie & 0.175 & 10 & 0.078 & 15 & 0.302 & 6 & 0.545 & 5 & 0.185 & 7 \\
\hline $\begin{array}{l}\text { Warmińsko- } \\
\text { mazurskie }\end{array}$ & 0.277 & 4 & 0.175 & 9 & 0.253 & 8 & 0.741 & 2 & 0.333 & 3 \\
\hline Wielkopolskie & 0.335 & 1 & 0.123 & 12 & 0.136 & 14 & 0.374 & 9 & 0.085 & 15 \\
\hline $\begin{array}{l}\text { Zachodnio- } \\
\text { pomorskie }\end{array}$ & 0.291 & 2 & 0.340 & 2 & 0.575 & 1 & 0.721 & 3 & 0.157 & 11 \\
\hline
\end{tabular}

Source: own elaboration.

On the basis of data included in Table 3 and Table 4 , it is visible that in the ranking of Polish regions which was obtained with the use of Hellwig's pattern development method regards the amount of financial resources granted by the European Union for various projects (Table 1): 
- the leading positions, when taking into consideration the subsidies for the educational group of projects, were taken up by the provinces: wielkopolskie and zachodniopomorskie (in 2004-2006) and podkarpackie and warmińsko-mazurskie (in 2007-2013). Provinces such as: pomorskie (in 2004-2006) and lubuskie (in 2007-2013) were ranked at the end of the list;

- the leading positions, when taking into consideration the subsidies for the administrative group of projects, were taken up by the provinces: podlaskie and zachodniopomorskie (in 2004-2006) and podlaskie and mazowieckie (in 2007-2013). The łódzkie province was found at the end of the list when it comes to both periods;

- the leading positions, when taking into consideration the subsidies for the environmental group of projects, were taken up by the provinces: zachodniopomorskie and opolskie (in 2004-2006) and śląskie and pomorskie (in 2007-2013). The provinces śląskie (in 2004-2006 ) and podlaskie (in 2007-2013) were found at the end of the list;

- the leading positions, when taking into consideration the subsidies for the employment and development group of projects, were taken up by the provinces: podlaskie and warmińsko-mazurskie (in 2004-2006) and warmińsko-mazurskie and lubelskie (in 2007-2013). The śląskie province was ranked at the end of the list when it comes to both periods;

- the leading positions, when taking into consideration the subsidies for the other group of projects, were taken up by the provinces: lubelskie and podlaskie (in 2004-2006) and warmińsko-mazurskie and podlaskie (in 20072013). The małopolskie province was found at the end of the list in both tested periods.

In the further part of the conducted research, using the spatial statistics, it was examined whether the localization of a particular province in relevance to neighboring provinces influences the amount of the European fund subsidy for projects (in other words, whether it depends on the geographic localization or not).

The research of the spatial dependence of provinces in Poland was conducted with the assumption of contiguity based weights (according to the common borders criterion). Table 5 contains the calculated values of the Global Moran's I statistics. 
Table 4. Values of synthetic measure for Polish regions in 2007-2013 defined according to Hellwig's method

\begin{tabular}{|c|c|c|c|c|c|c|c|c|c|c|}
\hline \multirow{3}{*}{ Province } & \multicolumn{10}{|c|}{ Synthetic measure according to Hellwig's method } \\
\hline & \multicolumn{2}{|c|}{ Education } & \multicolumn{2}{|c|}{ Administration } & \multicolumn{2}{|c|}{ Environment } & \multicolumn{2}{|c|}{$\begin{array}{c}\text { Employment } \\
\text { and development }\end{array}$} & \multicolumn{2}{|c|}{ Other } \\
\hline & $Z_{i}$ & Rank & $Z_{i}$ & Rank & $Z_{i}$ & Rank & $Z_{i}$ & Rank & $Z_{i}$ & Rank \\
\hline Dolnośląskie & 0.458 & 3 & 0.204 & 9 & 0.264 & 10 & 0.386 & 9 & 0.261 & 9 \\
\hline $\begin{array}{l}\text { Kujawsko- } \\
\text { pomorskie }\end{array}$ & 0.169 & 11 & 0.108 & 12 & 0.260 & 11 & 0.485 & 7 & 0.252 & 10 \\
\hline Lubelskie & 0.447 & 4 & 0.196 & 10 & 0.243 & 13 & 0.700 & 2 & 0.323 & 6 \\
\hline Lubuskie & 0.064 & 16 & 0.235 & 7 & 0.622 & 3 & 0.307 & 10 & 0.231 & 11 \\
\hline Łódzkie & 0.339 & 8 & 0.028 & 16 & 0.254 & 12 & 0.408 & 8 & 0.282 & 8 \\
\hline Małopolskie & 0.387 & 5 & 0.217 & 8 & 0.475 & 7 & 0.247 & 12 & 0.075 & 16 \\
\hline Mazowieckie & 0.474 & 2 & 0.253 & 5 & 0.198 & 15 & 0.200 & 15 & 0.332 & 5 \\
\hline Opolskie & 0.344 & 7 & 0.303 & 4 & 0.546 & 4 & 0.264 & 11 & 0.183 & 13 \\
\hline Podkarpackie & 0.377 & 6 & 0.360 & 1 & 0.199 & 14 & 0.533 & 6 & 0.418 & 4 \\
\hline Podlaskie & 0.521 & 1 & 0.312 & 3 & 0.049 & 16 & 0.603 & 5 & 0.482 & 2 \\
\hline Pomorskie & 0.296 & 10 & 0.244 & 6 & 0.633 & 2 & 0.240 & 13 & 0.206 & 12 \\
\hline Śląskie & 0.089 & 15 & 0.164 & 11 & 0.842 & 1 & 0.092 & 16 & 0.127 & 15 \\
\hline Świętokrzyskie & 0.328 & 9 & 0.085 & 14 & 0.514 & 6 & 0.667 & 3 & 0.429 & 3 \\
\hline $\begin{array}{l}\text { Warmińsko- } \\
\text { mazurskie }\end{array}$ & 0.127 & 13 & 0.338 & 2 & 0.397 & 8 & 0.877 & 1 & 0.698 & 1 \\
\hline Wielkopolskie & 0.146 & 12 & 0.060 & 15 & 0.393 & 9 & 0.237 & 14 & 0.163 & 14 \\
\hline $\begin{array}{l}\text { Zachodnio- } \\
\text { pomorskie }\end{array}$ & 0.127 & 14 & 0.087 & 13 & 0.530 & 5 & 0.664 & 4 & 0.302 & 7 \\
\hline
\end{tabular}

Source: own elaboration.

Analyzing Table 5, it is visible that in the case of two categories (employment and other objectives) in 2004-2006 there is a similarity of provinces in the amount of subsidies granted by the European Union for realized projects. The similarity is statistically significant on the level of significance equal to $\alpha=0.5$.

The graphic presentation of the Global Moran's statistics is the scatter plot of the statistics (Figures 3 and 4) which presents the local spatial associations and non-standardized observations. The points located in the bottom left quarter of the graph (LL) indicate the clustering of provinces with similar low values, while the points located in the top right quarter indicate the clustering 
of provinces with similar high values. In Figure 3, there is a division of provinces according to the affiliation to the quarters of the Moran scatter plot for the measure of development. The lightest grey color is assigned to the provinces with the most favorable situation, according to the amount of the project subsidies granted by the European Union, which create clusters of high values. The middle grey color is assigned to the provinces with the low values, clustered among the areas similar in values.

Table 5. Values of the Global Moran's I statistics for the synthetic measure of development of Hellwig's method

\begin{tabular}{|l|c|c|c|c|c|}
\hline \multirow{2}{*}{ Category } & \multirow{2}{*}{ Period } & \multicolumn{4}{|c|}{ Global Moran's I statistics } \\
\cline { 3 - 6 } & & $\mathrm{I}$ & $\mathrm{Ec}$ & Var c & p-value \\
\hline \multirow{2}{*}{ Education } & $2004-06$ & -0.2553 & -0.0667 & 0.0224 & 0.896 \\
\cline { 2 - 6 } & $2007-13$ & 0.1164 & -0.0667 & 0.0241 & 0.119 \\
\hline \multirow{3}{*}{ Administration } & $2004-06$ & 0.1370 & -0.0667 & 0.0231 & 0.089 \\
\cline { 2 - 6 } & $2007-13$ & 0.0344 & -0.0667 & 0.0236 & 0.255 \\
\hline \multirow{3}{*}{ Environment } & $2004-06$ & -0.2780 & -0.0667 & 0.0216 & 0.925 \\
\cline { 2 - 6 } & $2007-13$ & 0.1793 & -0.0667 & 0.0224 & 0.050 \\
\hline \multirow{2}{*}{$\begin{array}{l}\text { Employment } \\
\text { and development }\end{array}$} & $2004-06$ & 0.3421 & -0.0667 & 0.0226 & 0.003 \\
\cline { 2 - 6 } & $2007-13$ & -0.0504 & -0.0667 & 0.0231 & 0.457 \\
\hline \multirow{2}{*}{ Other } & $2004-06$ & 0.2586 & -0.0667 & 0.0230 & 0.016 \\
\cline { 2 - 6 } & $2007-13$ & 0.1623 & -0.0667 & 0.0196 & 0.052 \\
\hline
\end{tabular}

Source: own elaboration.

Analyzing Figures 3 and 4 protruding, non-standardized observations are clearly visible, i.e. the provinces which protrude significantly from other provinces. The conclusion from the above mentioned analysis of Figures 3 and 4 is that, in the 2004-2006 there was greater number of protruding provinces than in the 2007-2013. Between 2004 and 2006 the protruding provinces were as follows (according to the project category): pomorskie, warmińsko-mazurskie and wielkopolskie (educational category); łódzkie and podlaskie (administrative category); zachodniopomorskie and opolskie (environmental category); śląskie and podlaskie (employment and development category); małopolskie, mazowieckie and lubelskie (other categories). When it comes to the period of 2007-2013, provinces such as: lubuskie (educational category); łódzkie (administrative category); śląskie (environmental category); śląskie and warmińsko-mazurskie (employment and development category); warmińsko-mazurskie (other categories) were described as protruding. 


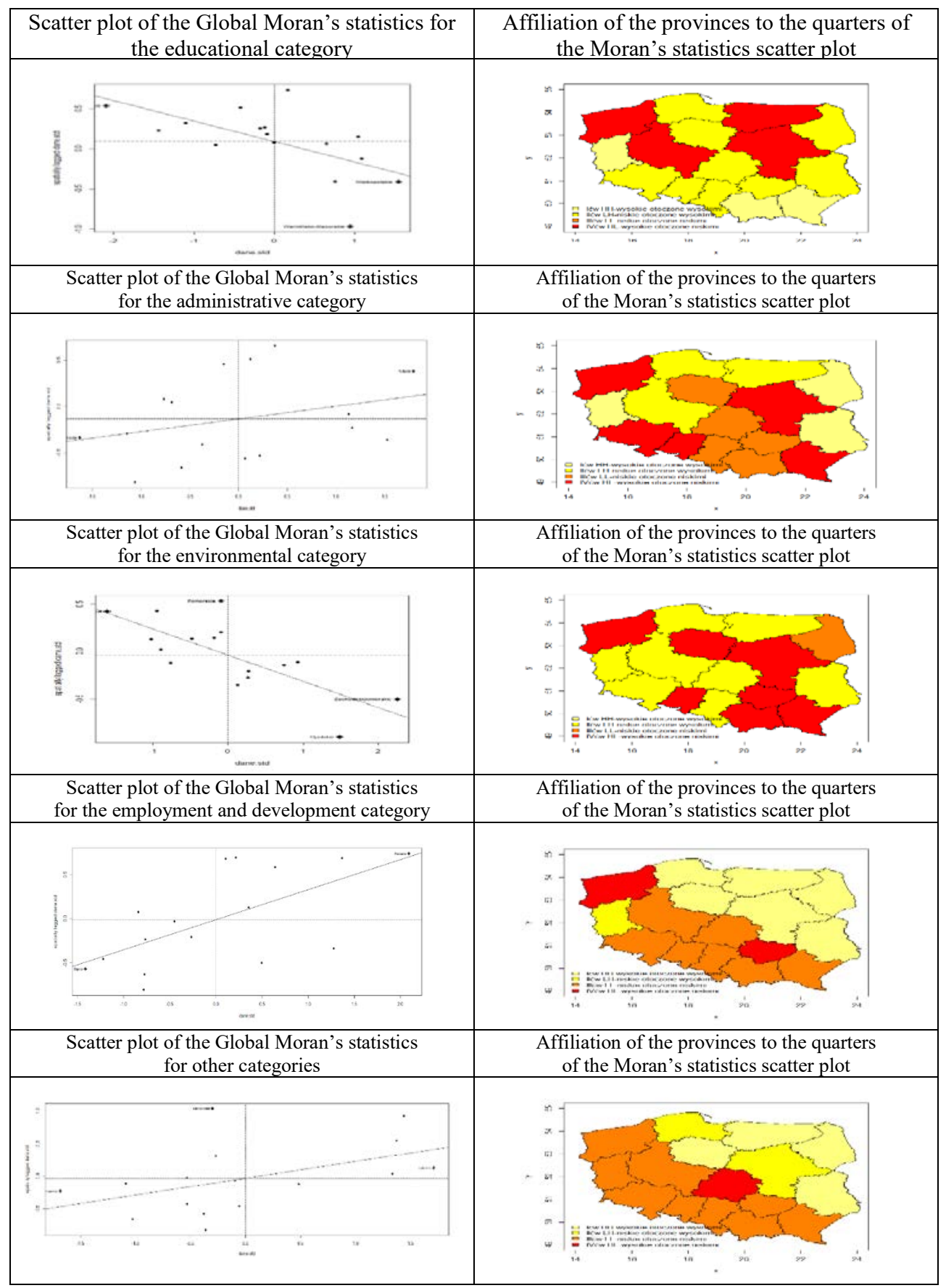

Fig. 3. The Global Moran's statistics graphs in 2004-2006

Source: own elaboration. 


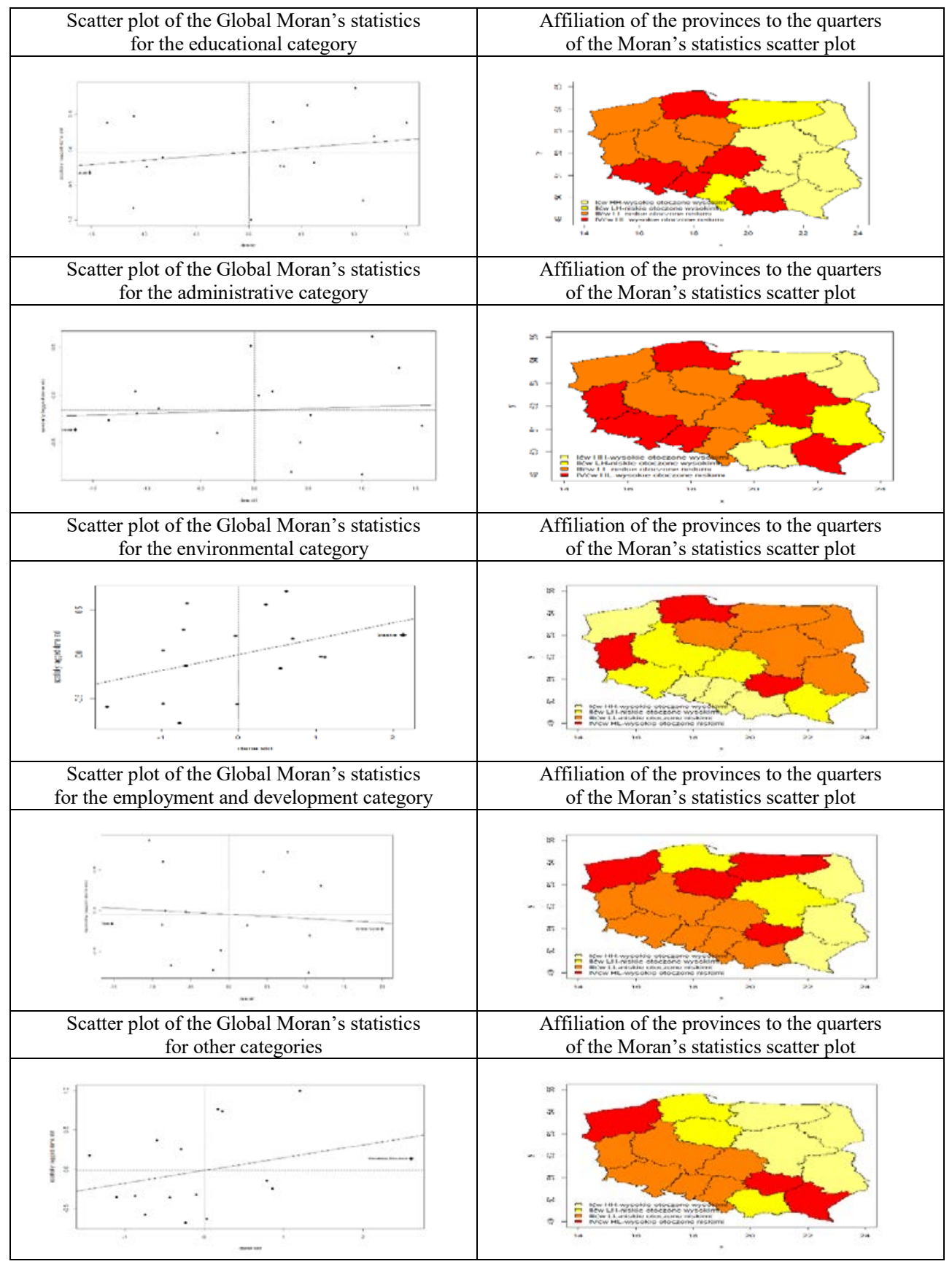

Fig. 4. The Global Moran's statistics graphs in 2007-20013

Source: own elaboration. 
The last stage of the research was calculation of the Local Moran's $I_{i}$ statistics and marking those which are significant statistically (with the level of significance 0.05 - values written in boldface) in Table 6 and Table 7. For the majority of provinces the Local Moran's statistics were statistically insignificant $(0.05<\mathrm{p}$-value $<0.95)$. The $\mathrm{p}$-value which is less than 0.05 indicates that the significant positive spatial autocorrelation occurs, while values are higher than 0.95 indicates the significant negative local autocorrelation.

Table 6. Local Moran's $I_{i}$ statistics of Hellwig's measure of development in 2004-2006

\begin{tabular}{|c|c|c|c|c|c|c|c|c|c|c|}
\hline \multirow{3}{*}{ Province } & \multicolumn{10}{|c|}{ The Local Moran's statistics } \\
\hline & \multicolumn{2}{|c|}{ Education } & \multicolumn{2}{|c|}{ Administration } & \multicolumn{2}{|c|}{ Environment } & \multicolumn{2}{|c|}{$\begin{array}{c}\text { Employment and } \\
\text { development }\end{array}$} & \multicolumn{2}{|c|}{ Other } \\
\hline & $I_{i}$ & p-value & $I_{i}$ & p-value & $I_{i}$ & p-value & $I_{i}$ & $\mathrm{p}$-value & $I_{i}$ & $\mathrm{p}$-value \\
\hline Dolnośląskie & -0.231 & 0.626 & -0.098 & 0.524 & -0.019 & 0.462 & 0.524 & 0.125 & 0.726 & 0.062 \\
\hline $\begin{array}{l}\text { Kujawsko- } \\
\text { pomorskie }\end{array}$ & -0.351 & 0.782 & 0.164 & 0.266 & -0.111 & 0.549 & 0.049 & 0.376 & 0.056 & 0.370 \\
\hline Lubelskie & -0.036 & 0.471 & 0.067 & 0.378 & -0.140 & 0.569 & 0.399 & 0.138 & 0.232 & 0.244 \\
\hline Lubuskie & 0.132 & 0.349 & 0.260 & 0.263 & -0.070 & 0.503 & -0.069 & 0.502 & 0.324 & 0.224 \\
\hline Łódzkie & -0.001 & 0.418 & 0.586 & 0.021 & -0.028 & 0.452 & 0.192 & 0.209 & -0.064 & 0.496 \\
\hline Małopolskie & 0.163 & 0.326 & 0.414 & 0.176 & -0.049 & 0.486 & 0.598 & 0.097 & 0.413 & 0.176 \\
\hline Mazowieckie & -0.331 & 0.796 & -0.285 & 0.752 & -0.115 & 0.561 & 0.159 & 0.241 & -0.334 & 0.797 \\
\hline Opolskie & -0.049 & 0.484 & -0.041 & 0.476 & -1.432 & 0.999 & 0.677 & 0.041 & 0.240 & 0.238 \\
\hline Podkarpackie & 0.043 & 0.412 & -0.124 & 0.544 & -0.060 & 0.494 & 0.015 & 0.437 & 0.014 & 0.438 \\
\hline Podlaskie & -0.379 & 0.729 & 0.725 & 0.063 & 0.099 & 0.371 & 1.649 & 0.000 & 1.423 & 0.002 \\
\hline Pomorskie & -1.192 & 0.996 & -0.064 & 0.497 & -0.052 & 0.486 & 0.074 & 0.371 & -0.090 & 0.521 \\
\hline Śląskie & -0.017 & 0.454 & 0.930 & 0.010 & -0.726 & 0.941 & 0.863 & 0.015 & 0.029 & 0.412 \\
\hline Świętokrzyskie & -0.034 & 0.460 & 0.359 & 0.093 & -0.079 & 0.515 & -0.265 & 0.732 & 0.007 & 0.410 \\
\hline $\begin{array}{l}\text { Warmińsko- } \\
\text { mazurskie }\end{array}$ & -0.976 & 0.984 & -0.073 & 0.506 & -0.020 & 0.455 & 1.006 & 0.066 & 0.806 & 0.021 \\
\hline Wielkopolskie & -0.680 & 0.985 & -0.034 & 0.454 & -0.435 & 0.905 & 0.059 & 0.328 & 0.126 & 0.248 \\
\hline $\begin{array}{l}\text { Zachodnio- } \\
\text { pomorskie }\end{array}$ & -0.147 & 0.562 & -0.582 & 0.841 & -1.210 & 0.988 & -0.458 & 0.777 & 0.233 & 0.281 \\
\hline
\end{tabular}

The values of statistically significant statistics (with the level of significance of 0.05 ) were written in boldface.

Source: own elaboration. 
Between 2004 and 2006, the Local Moran's statistics (for administrative category) for the łódzkie and śląskie provinces is significant and higher than 0 , which means that these provinces are surrounded by the provinces with significantly similar values of the tested variable. The similar significant Local Moran's statistics could be found in the employment and development category for the provinces such as: śląskie, podlaskie and opolskie. The Local Moran's statistics (for other categories) belong to the same group and, for the provinces: podlaskie and warmińsko-mazurskie, is significant and higher than 0 . The above mentioned provinces are called clusters.

Table 7. Local Moran's $I_{i}$ statistics of Hellwig's measure of development in 2007-2013

\begin{tabular}{|c|c|c|c|c|c|c|c|c|c|c|}
\hline \multirow{3}{*}{ Province } & \multicolumn{10}{|c|}{ The Local Moran's statistics } \\
\hline & \multicolumn{2}{|c|}{ Education } & \multicolumn{2}{|c|}{ Administration } & \multicolumn{2}{|c|}{ Environment } & \multicolumn{2}{|c|}{$\begin{array}{c}\text { Employment and } \\
\text { development }\end{array}$} & \multicolumn{2}{|c|}{ Other } \\
\hline & $I_{i}$ & $\mathrm{p}$-value & $I_{i}$ & p-value & $I_{i}$ & $\mathrm{p}$-value & $I_{i}$ & p-value & $I_{i}$ & p-value \\
\hline Dolnośląskie & -0.835 & 0.929 & -0.001 & 0.449 & -0.408 & 0.748 & 0.161 & 0.330 & 0.176 & 0.316 \\
\hline $\begin{array}{l}\text { Kujawsko- } \\
\text { pomorskie }\end{array}$ & 0.098 & 0.329 & 0.139 & 0.290 & 0.091 & 0.333 & -0.045 & 0.476 & -0.079 & 0.514 \\
\hline Lubelskie & 0.942 & 0.010 & -0.019 & 0.456 & 0.633 & 0.050 & 0.396 & 0.141 & 0.135 & 0.311 \\
\hline Lubuskie & 0.531 & 0.127 & -0.293 & 0.668 & -0.032 & 0.472 & 0.008 & 0.443 & 0.169 & 0.315 \\
\hline Łódzkie & -0.074 & 0.509 & 0.646 & 0.014 & -0.211 & 0.674 & 0.055 & 0.353 & 0.036 & 0.371 \\
\hline Małopolskie & -0.124 & 0.544 & 0.006 & 0.444 & 0.214 & 0.291 & 0.005 & 0.445 & -0.273 & 0.664 \\
\hline Mazowieckie & 0.240 & 0.172 & -0.117 & 0.562 & 0.579 & 0.021 & -0.951 & 0.997 & 0.176 & 0.218 \\
\hline Opolskie & -0.084 & 0.515 & -0.889 & 0.971 & 0.133 & 0.319 & 0.545 & 0.078 & 0.464 & 0.097 \\
\hline Podkarpackie & 0.369 & 0.203 & -0.540 & 0.819 & -0.047 & 0.484 & 0.229 & 0.283 & -0.120 & 0.544 \\
\hline Podlaskie & 0.593 & 0.104 & 0.714 & 0.067 & 1.063 & 0.013 & 0.589 & 0.102 & 1.277 & 0.003 \\
\hline Pomorskie & -0.021 & 0.458 & -0.227 & 0.644 & -0.035 & 0.471 & -0.550 & 0.869 & -0.233 & 0.658 \\
\hline Śląskie & -0.535 & 0.859 & 0.148 & 0.310 & 0.503 & 0.090 & 0.258 & 0.225 & 0.428 & 0.113 \\
\hline Świętokrzyskie & 0.096 & 0.307 & -0.039 & 0.466 & -0.091 & 0.530 & -0.346 & 0.808 & -0.226 & 0.695 \\
\hline $\begin{array}{l}\text { Warmińsko- } \\
\text { mazurskie }\end{array}$ & -0.553 & 0.868 & 0.413 & 0.134 & 0.011 & 0.427 & -0.474 & 0.828 & 0.366 & 0.145 \\
\hline Wielkopolskie & 0.251 & 0.131 & 0.381 & 0.057 & -0.008 & 0.418 & 0.160 & 0.211 & 0.320 & 0.082 \\
\hline $\begin{array}{l}\text { Zachodnio- } \\
\text { pomorskie }\end{array}$ & 0.968 & 0.024 & 0.229 & 0.284 & 0.472 & 0.146 & -0.848 & 0.945 & -0018 & 0.461 \\
\hline
\end{tabular}

The values of statistically significant statistics (with the level of significance of 0.05 ) were written in boldface.

Source: own elaboration. 


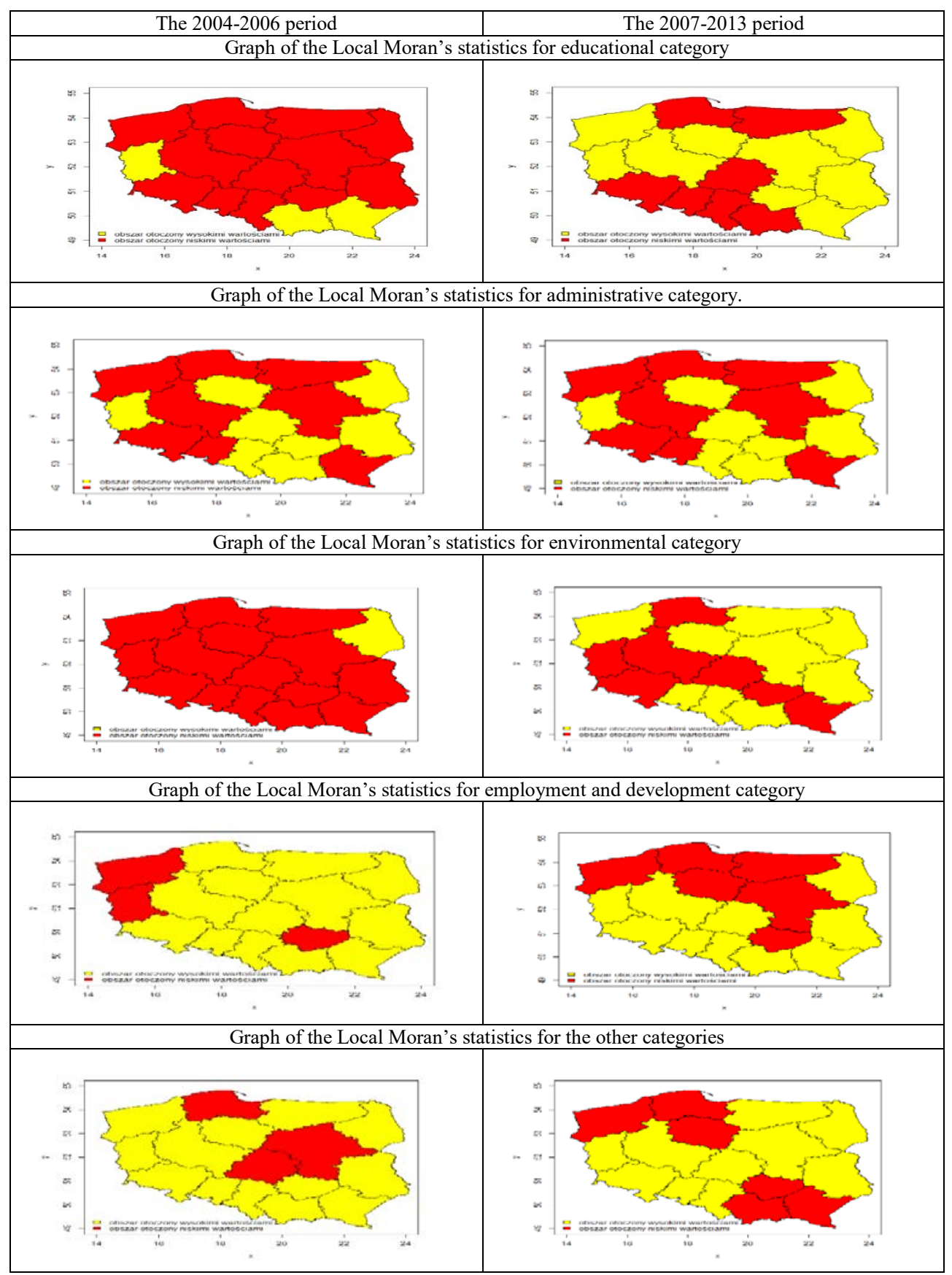

Fig. 5. Graph of the Local Moran's statistics for particular categories of variables Source: own elaboration. 
The significant negative spatial autocorrelation in 2004-2006 occurred in the educational category in: pomorskie, warmińsko-mazurskie and wielkopolskie provinces. When it comes to environmental category, there were the opolskie and zachodniopomorskie provinces. The above mentioned provinces are so called hot spots, i.e. they are the islands surrounded by the provinces which possess dissimilar values (high or low).

In the 2007-2013 period, the clusters were created from such provinces as: lubelskie and zachodniopomorskie (in educational category), łódzkie (in administrative category), mazowieckie and podlaskie (in environmental category) and podlaskie (in employment category). When it comes to the opolskie province (in administrative category) and the mazowieckie province (in employment and development category) they can be grouped as hot spots.

In addition, comparing the results from Tables 6 and 7 and Figure 5, we can observe whether the appropriate clusters and hot spots are surrounded by the areas with the high (dark color) or the low (light color) values.

\section{Conclusions}

The use of methods of spatial statistics in the provinces arrangement allowed us to do the analysis of the use of European funds in Poland between 2004-2013. According to the subject literature the spatial methods are used more frequently in the analyses of economic and demographic processes [Zeug-Żebro 2014 pp. 100-113; Miśkiewicz-Nawrocka, Zeug-Żebro 2015, pp. 43-55; Warzecha, Wójcik 2015, pp. 912-918].

On the basis of conducted research, it can be asserted that thanks to the European funds the provinces in Poland are developing. The co-financing of projects by the European Union influences the development of education, public administration and culture. The most polluted regions in Poland are able to improve the state and the quality of the environment - this is a result of considerable support for the projects connected with the environmental protection. Many companies, private as well as public ones, have taken advantage of the subsidies and invested in their development. There is an improvement in the public health sector. Undoubtedly, all of the provinces make use of the money granted by the European Union. The aim of this paper was the examination whether the most indigent provinces have the same priorities and whether they obtain the most substantial financial support for particular purposes. 
The examined projects which were subsidized from European Union funds in 2004-2013 have been divided into 5 thematic categories: education, administration, environment, employment and development and other Table 1.

It results from the research that some of the provinces are significantly similar (positive autocorrelation), according to the obtained funds for the projects connected with particular purposes, to neighboring provinces. There are also some provinces which are significantly dissimilar as regards the obtained funds.

Between 2004 and 2006, in the śląskie and łódzkie provinces there was a substantial financial support for the projects connected with administration. Additionally, the śląskie and łódzkie provinces were surrounded by the provinces which obtained high financial support as well. The provinces such as: opolskie, podlaskie and ślaskie in the employment and development categories create clusters as well, and they are surrounded by the provinces with the high subsidy for the projects that are the part of the same category.

The podlaskie and warmińsko-mazurskie provinces obtained substantial subsidies for projects connected with power, transport, tourism, telecommunications and e-services and finally with healthcare. Those provinces are surrounded by the provinces with the funds remaining on the high level.

In the 2007-2013 period, in educational category, the clusters were created by the lubelskie and zachodniopomorskie provinces - the subsidies for the projects connected with the education were there at a low level; in the administrative category, once again, the expenses for administration were at a high level and this province created a cluster.

The substantial financial support for projects connected with the environmental protection between 2007 and 2013 occurred in the mazowieckie and podlaskie provinces and also in neighboring provinces, and in the category with other purposes the cluster was created by the podlaskie province, where the subsidy was substantial again.

Undoubtedly, the most indigent provinces (the lowest GNP) obtain more substantial subsidies for the projects per 1 resident than the wealthy provinces. Additionally, it can be said that at least in some categories, their objectives (i.e. targeting the projects for specific purposes) are the same as those of neighboring provinces. The clusters are created more frequently by less indigent provinces, moreover, the financial support is at a high level inside those clusters. 


\section{Bibliography}

Anselin L. (1995). Local Indicators of Spatial Association-LISA. Geographical Analysis 27. Berbeka J. (2006). Poziom życia ludności a wzrost gospodarczy w krajach Unii Europejskiej. AE. Kraków.

Heffner K., Gibas P. (2007). Analiza ekonomiczno-przestrzenna. AE. Katowice.

Kopczewska K. (2011). Ekonometria i statystyka przestrzenna z wykorzystaniem programu $R$ Cran. CeDeWu. Warszawa.

Miśkiewicz-Nawrocka M., Zeug-Żebro K. (2015). Zastosowanie statystyk przestrzennych w analizie dostępności do infastruktury ICT w Polsce. In: Nierówności Społeczne a Wzrost Gospodarczy nr 44 (4/2015), część 2. Wydawnictwo Uniwersytetu Rzeszowskiego. Rzeszów.

Suchecki B. (ed.) (2010). Ekonometria przestrzenna. Metody i modele analizy danych przestrzennych. Wydawnictwo C.H. Beck. Warszawa.

Warzecha K. (2009). Poziom życia ludności Polski i pozostałych krajów Unii Europejskiejanaliza taksonomiczna. In: Gospodarka polska po 20 latach transformacji: osiagnięcia, problemy i wyzwania. S. Pongsy-Kania (ed.). Instytut Wiedzy i Innowacji. Warszawa.

Warzecha K., Wójcik A. (2015). Analysis of the Availability of Internet Access for Young People in Schools of Silesia Province Based on Spatial Statistics. In: Proceedings of 33rd International Conference Mathematical Methods in Economics. D. Martincik, J. Ircingova P. Janecek (eds.). University of West Bohemia. Plzen, pp. 912-918.

Zeliaś A. (ed.) (1989). Metody taksonomii numerycznej w modelowaniu zjawisk spolecznogospodarczych. PWN. Warszawa.

Zeliaś A. (ed.) (2000). Taksonomiczna analiza przestrzennego zróżnicowania poziomu życia $w$ Polsce w ujęciu dynamicznym. AE. Kraków.

Zeug-Żebro K. (2014). Analiza zjawiska starzenia się ludności w ujęciu przestrzennym. Studia Ekonomiczne Uniwersytetu Ekonomicznego nr 141. Katowice.

[www 1] http://www.mapadotacji.gov.pl (10.12.2014). 